The Egyptian Journal of Hospital Medicine (Jan. 2015) Vol. 58, Page 129-142

\title{
Protective and Curative Effect of Thymoquinone on Ehrlich Solid Carcinoma Inoculated Mice
}

\author{
Sayed K. Areida, Amira O. Abd El-Azim and Maggie E. Amer \\ Zoology Department, Faculty of Science, Mansoura University, Mansoura, Egypt \\ Corresponding Author: Dr. Sayed Kamel Areida, E mail:areida2002@yahoo.com
}

\begin{abstract}
Background: Thymoquinone (TQ), the main constituents of the volatile oil from Nigella sativa seeds and it is reported to protect laboratory animals against chemical toxicity and induction of carcinogenesis. This study was undertaken to investigate the potential protective and curative effect of TQ on Ehrlich solid carcinoma cells (ESC) inoculated mice-induced carcinogenesis. Material and methods: (50) Swiss albino mice were divided into five groups. Control group, Thymoquonone group: animals of this group were orally treated with TQ $(10 \mathrm{mg} / \mathrm{kg} /$ day $)$ for 4 weeks, Ehrlich Carcinoma group : animals of this group were inoculated intramuscularly with $0.2 \mathrm{~mL}$ Ehrlich Ascites Carcinoma $\left(2.5 \times 10^{6}\right.$ cells $)$ in the right thigh of the lower limb, Thymoquinone and Ehrlich carcinoma group: animals of this group were pre-treated with TQ for 14 days then inoculated with (EAC) and Ehrlich Carcinoma and Thymoquinone group : in this group animals were inoculated with EAC then after 8 days received TQ orally for a month. Morphological, Molecular as well as histopathological and ultrastructural changes were examined. Results: Our results revealed that TQ showed a significant anti-tumor activity in ESC bearing mice represented by a reduction in tumor weight and volume. Flow cytometric analysis illustrated that the level of apoptosis is significantly decreased in ESC inoculated group. Otherwise, TQ+ESC and ESC+TQ groups showed a highly significant increase in apoptosis G0/1 peak. The level of P53 protein expression showed a significant decrease in ESC inoculated group, and this decrease was ameliorated in TQ+ESC and ESC+TQ groups when compared to ESC inoculated group. Histopathological observations showed a reduction in tumor size after treatment with Thymoquinone and this tumor was found to be discontinuous and fragmented with slowly growing. Conclusion: our results revealed that TQ has potential benefits in the prevention of the onset and progression of solid tumor model in mice.
\end{abstract}

Key Words: Thymoquinone, Anti-tumor activity, Ehrlich ascites carcinoma, Ehrlich solid tumor

\section{INTRODUCTION}

Thymoquinone (TQ) is a naturallyoccurring volatile oil extracted from (Nigella sativa) seeds. Previous studies on TQ showed in vitro and in vivo anticancer, anti-inflammatory and anti-oxidant activities. ${ }^{[1]}$ The combination of TQ with other natural compounds like diosgenin exhibited antineoplastic activity against squamous cell carcinoma in vitro and sarcoma180-induced tumors in vivo. ${ }^{[2]}$ Effect of TQ as an immunomodulator was also reported. [3] Toxicity studies showed that $\mathbf{T Q}$ can reduce the hepatotoxicity induced by some compounds including carbon tetrachloride, ${ }^{[4]}$ tert-butyl hydroperoxide, ${ }^{[5]}$ and cyclophosphamide. ${ }^{[6]}$ Furthermore, TQ had no effect on liver integrity and hepatic enzyme activity when tested on mice and rats. ${ }^{[7]}$ Importantly, the intraperitoneal therapeutic dose of TQ is $10-15$ times lower than its $\mathrm{LD}_{50}$ value in rats. ${ }^{[8]}$ Thus, it is

reasonable to assume that $\mathbf{T Q}$ is a safe compound and has the potential to work as a therapeutic and hepatoprotective agent. Many potential targets which TQ regulates for its anticancer activities have been identified including p53, p73. [9] In addition, the combination of TQ with conventional medicine can result in greater anticancer effect, for example in NCI-H460 non-small cell lung cancer cells multiple myeloma cells. ${ }^{[10]}$

Solid Ehrlich tumor is an undifferentiated solid tumor that is frequently used in tumor studies. It is both used to develop a tumor model and in chemotherapy investigations. [11] Following subcutaneous

DOI: $10.12816 / 0009367$ 
injection of Ehrlich tumor cells, a tumor of $1 \mathrm{~cm}$ in diameter is obtained approximately within 1 week. This highly virulent tumor causes death of almost $100 \%$ of the experimental animals in a short period. Large-scale virulence, quick development and infiltrative nature of the tumor reflect its high-grade malignancy. ${ }^{[12]}$ Tumor growth can cause antioxidant disturbances in certain tissues of the tumor host. ${ }^{[13]}$ One of the characteristics of tumor growth and invasion is the increased flux of oxy-radicals and loss of cellular redox homeostasis. Cancer cells can generate large amounts of hydrogen peroxide, which may contribute to their ability to mutate, damage normal tissues and invade other tissues. This suggests that there is a direct correlation between changes in the rate of cancer cell proliferation and changes in the antioxidant machinery. Furthermore, some anticancer agents can act as antioxidant. ${ }^{[14]}$

This study aimed to investigate the potential protective and curative effect of $\mathbf{T Q}$ on Ehrlich solid carcinoma cells (ESC) inoculated mice-induced carcinogenesis.

\section{Material and Methods \\ Chemicals}

Thymoquinone (TQ) was purchased from Sigma-Aldrich Company Ltd. All other reagents and chemicals used in this study were of analytical and molecular grade.

\section{Animals}

Male Swiss albino mice, 6-8 weeks old weighting $19 \pm 2 \mathrm{~g}$ were kept for7 days with free access to water ad libitum and fed on balanced diet.

Mice were divided into five groups, 10 mice for each one. Group 1, (C) served as the normal control. Animals of this group did not receive any treatment for 4 weeks. Group2, (TQ) was dissolved in bi distilled water and orally administrated to mice at a dose of $10 \mathrm{mg} / \mathrm{kg} / \mathrm{day}$ for consecutive 4 weeks based on LD50. ${ }^{[15,16]}$ Group3, (ESC), mice were inoculated intramuscularly with $0.2 \mathrm{~mL}$ Ehrlich Ascites Carcinoma (EAC) $\left(2.5 \times 10^{6}\right.$ cells $)$ in the right thigh of the lower limb at the first day of the experiment then left for 4 weeks. ${ }^{[17]}$ Group 4, (TQ+ESC), mice were orally pre-treated with TQ $(10 \mathrm{mg} / \mathrm{kg} /$ day $)$ for 2 weeks then inoculated intramuscularly with $0.2 \mathrm{~mL}$ (EAC) $\left(2.5 \times 10^{6}\right.$ cells) in the right thigh of the lower limb then left for extra 2 weeks. Group 5, (ESC+TQ), mice were inoculated intramuscularly with $0.2 \mathrm{~mL}$ (EAC) $\left(2.5 \times 10^{6}\right.$ cells) in the right thigh of the lower limb then after 8 days they received TQ $(10 \mathrm{mg} / \mathrm{kg} /$ day) orally for successive 4 weeks. At the end of the experiment, mice were sacrificed and the samples were collected,

\section{Body weight Changes}

Animals were examined for BW changes: (initial BW on day 0 , last and net final BWs on day 30). Net final BW $=$ (final BW - tumor weight). BW gain was determined as body weight gain (final BW-intial BW/initialBW) x100.

Tumor volume (TV) and tumor weight (TW) analysis.

Time interval measurements of TV using digital Vernier calipers were conducted from day 8 to day 30 ESC and ESC+TQ groups. Data collected were plugged into the following formula to obtain tumor volume: TV $(\mathrm{mm} 3)=$ $0.52 A B 2$, where $A$ is the minor axis and $\mathrm{B}$ is the major axis. On day 30 , mice were euthanized and solid tumors were excised for TW determination, photographed for tumor regression and processed for the histopathological studies

\section{Apoptosis as determined by flow cytometry}

The flow cytometric analysis was performed in the Mansoura University Hospital using FACS (Flow activated cell sorter) Calibur Flow Cytometer (Becton Dickinson, Sunnyvale, CA, USA) equipped with a compact air-cooled low power $15 \mathrm{~m}$ WArgon ion laser beam $(488 \mathrm{~nm})$. DNA histogram derived from flow cytometry was obtained with a computer program for Dean and Jett mathematical analysis. ${ }^{[18]}$ This software calculated the percentage of cells in each phase (G0/G1, S and G2/M) of the DNA cell cycle for each sample. The analysis of apoptotic cell death was performed by measuring DNA content. ${ }^{[19]}$ Flow cytometry P53 protein expression was performed using fluorescence threshold using FACS Calibur Flow Cytometer (Becton Dickinson, Sunnyvale, CA, USA). ${ }^{[20]}$

\section{The histopathological examination}

Liver and tumor tissues were collected from mice, washed carefully by cold normal saline 3 times, then fixed in formalin solution $10 \%$, 
processed and embedded in a paraffin wax. Sections of $4-\mu \mathrm{m}$ thickness were cut. Slides were stained with haematoxylin and eosin for the histological examination.

Electronic Microscopy.

Liver and tumor tissue were fixed, for 2 hours, in $2.5 \%$ glutaraldehyde buffered in $0.1 \mathrm{M}$ cacodylate buffer ( $\mathrm{pH} 7.2)$ at $4 \mathrm{oC}$ and post fixed in $1 \%$ cold osmium tetraoxide in $0.1 \mathrm{M}$

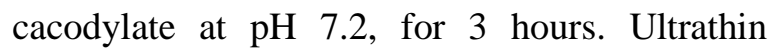
sections were obtained from specimens embedded in Lowicryl $\mathrm{K} 4 \mathrm{M}$ resin after dehydration through graded ethanol series, substitution and polymerization at $-200 \mathrm{C}$. [21] Ultrathin sections were obtained using an Ultracut S microtome (Leica,Vienna, Austria). Sections were mounted on 400-mesh collodioncarbon-coated nickel grids and examined with a Joel Electron Microscope (Japan) operating at 60 $\mathrm{kV}$.

\section{Statistical analysis}

All values are expressed as the mean \pm SE. Data were evaluated by using SPSS windows. The one way ANOVA test was used to examine whether there are any significant differences between the treatment groups and the value of $\mathrm{P}$ $<0.05$ was considered significant.

\section{RESULTS}

Protective effect of TQ on body weights and tumor sizes of Ehrlich solid tumor in mice:

Treatment of Ehrlich solid tumor in mice with TQ showed a significant $(\mathrm{P}<0.05)$ ability to reduce the tumor growth. Measuring the change in body weight showed a decrease in body weight for all treatments compared to the control TQ. The highest reduction in body weight was observed in Ehrlich solid tumor in mice (ESC) with a percentage change in body weight of $3.27 \%$ compared to $+33.48 \%$ recorded for untreated mice (Table 1). A slight increase in body weight was observed in mice treated with TQ, while mice treated with ESC-TQ showed a reduction in body weight (Table 1 ).

A significant decrease in tumor weight was observed in ESC+TQ treated group, as compared to ESC only inoculated mice. This represents $-69.47 \%(P<0.05)$ decreases. In otherwise, there was a complete absence of the tumor in TQ+ESC group compared to ESC inoculated group (Table 1).

A significant decrease in tumor volume was observed in ESC+TQ treated group, as compared to ESC only inoculated mice. This represents $-69.47 \%(P<0.05)$ decreases in tumor volume. Otherwise, there was a complete absence of the tumor in TQ+ESC treated group compared to ESC inoculated group (Fig. 1).

\section{Flowcytometric analysis of Ehrlich solid tumor cell cycle phase distribution.}

The cell cycle analysis of control and different treated mice groups were shown in table (2) and figures (2). Results illustrated that the level of apoptosis (sub G1) is significantly decreased in ESC inoculated group $(31.45 \pm 0.22)$. This decrease was overcome in TQ+ESC and ESC+TQ treated groups $(73.85 \pm 0.7)$ and (45.08 \pm 0.04$)$ respectively. Otherwise, TQ treated group showed non-significant change from the control group. The mean G0/1 peak showed a significant decline in ESC- inoculated group (12.26 \pm 0.14$)$. A decline was restored in TQ+ESC group which showed a highly significant increase in G0/1 peak $(23.73 \pm 0.34)$ and relative increase in ESC+TQ group (15.85 \pm 0.01 ) (Fig.2). On the other hand, S phase \% was not altered in the control and TQ group While, there was a significant increase in ESC inoculated group $(52.29 \pm 0.09)$ when compared to that of the control group, this percent declined in TQ+ESC and ESC+TQ groups when compared to ESC inoculated group; where they recorded 7.82 \pm 0.57 and $37.73 \pm 0.04$ respectively.

The mean G2/M peak was not altered in both the control and TQ treated group. While, there was a significant increase $(7.84 \pm 0.02)$ in ESC inoculated group when compared to that of control, this percent declined in TQ+ESC and ESC+TQ groups when compared to ESC inoculated only group since they showed $1.87 \pm 0.19$ and $5.72 \pm 0.01$ respectively (Fig.2).

Flow cytometric analysis of $\mathbf{p 5 3}$ protein expression.

The expression of p53 protein in Ehrlich solid tumor in mice is shown in Figure 3. The present results illustrated that the level of P53 protein 
expression (\%) was not significantly altered in both control and TQ treated groups. While, there was a significant decrease $(\mathrm{p}<0.05)$ in $\mathbf{E S C}$ inoculated group when compared to that of the control group. This decrease was ameliorated in TQ+ESC and ESC+TQ groups when compared to ESC inoculated group (Figs.3 A and B).

\section{Histopathology of Ehrlich solid tumor in mice:}

The inoculation of Ehrlich tumor cells into the control mice induced intramuscular tumors at the point of inoculation. These tumors were prominent and revealed fast growth with mixed inflammatory reaction predominantly lymphocytes, white conglomerated mass and sometimes infiltrated into the muscle fibres of the animals shown in figs. $4 \mathrm{~A} \& \mathrm{~B}$, also, a number of mitotic figures and lymphocytic reaction indicating a continuous proliferation activity in the positive control group. These tumors showed sheets of small, higher chromatophilic tumor cells of variable shapes representing cell proliferation surrounding areas of necrosis and differentiated cells as shown in figs.4A\&B. Necrosis was increased and marked reduction in the incidence of mitosis with extended necrosis, indicated slow growth. There was a marked reduction in tumor size after treatment with Thymoquinone, the tumor was found to be discontinuous and appeared growing slow and fragmented. This indicates a partial prevention of the effects of EAC cells by Thymoquinone.

Ultrastructurally, tumors isolated from Ehrlich tumor cells inoculated group revealed tumor cells without any apoptotic morphology. There were more or less rounded shape large nucleus quite euchromatic and quite evident nucleoli and a prominent porous nuclear envelope, besides electron-lucent nuclear vesicles dispersed in the nucleoplasm. There were also, threadlike processes projecting "microvilli" all-over the cells surface, some with bifurcation as shown in figs. $5 \mathrm{~A} \& \mathrm{~B}$ ). In some instances, the nuclei were fragmented and quite heterochromatic showed no nucleoli. The cytoplasm showed a depletion of organelles which was characterized by of free ribosomes and small degenerated mitochondria and lipid vesicles and abundant vacuoles. Some tumor cells had high amounts of glycogen, while others had high amounts of lipid in the cytoplasm, with occasional tumor cells having crescent-shaped nuclei partially encircling the lipid as shown in figs. 5A\&B.

Ultrastructurally, isolated tumors from post treated group with $\mathbf{T Q}$ showed changes in the shape of tumor cells. There were also some apoptotic cells which showed shrinkage rather than swelling, which was a morphologic feature of apoptosis. The cells were smaller in size with dense cytoplasm. The nuclear envelopes were deeply invaginated and sometimes broke up producing two or more fragments (karyorrhexis) as shown in figs. 5C\&D. Some nuclei underwent karyorrhexis (the nuclear chromatin was aggregated into numerous masses and being released by rupture of the nuclear envelope; the dark masses especially in the periphery probably represent fragmented nuclear remnants) and the others were pyknotic or karyolytic. The cytoplasm contained deformed mitochondria, short profiles of endoplasmic reticulum and abundant vacuoles. The cell surface had numerous projections. Sometimes these apoptotic cells showed surface blebbing and then underwent fragmentation of the cytoplasm as shown in figs. 5C\&D.

\section{DISCUSSION}

Thymoquinone (TQ), the main constituents of the volatile oil from Nigella sativa seeds is reported to protect laboratory animals against chemical toxicity and induction of carcinogenesis. In this regard, the present study was undertaken to evaluate the potential protective and curative effect of TQ on Ehrlich solid carcinoma cells inoculated animals-induced carcinogenesis. The mice inoculated with Ehrlich carcinoma showed a significant decrease in body weight gain with respect to the control ones. This result agrees with those obtained by Badr El-Din et al. ${ }^{[22]}$,Viela et al. ${ }^{[23]}$ and Metwally et al. ${ }^{[24]}$ Reduction in body weight resulted in the stunted growth not only due to reduced food consumption but also due to the tumor burden with its massive growth rate. Our results revealed that (TQ) exhibited antitumor activity against ESC tumor in mice, presented by the decrease in tumor weight and tumor volume .The reduction in body weight gain and the decrease in tumor volume are the criteria for 
judging on the volume of any antitumor drugs.

On the other hand, flow cytometric data revealed that mice inoculated with Ehrlich carcinoma showed remarkable alterations in cell cycle analysis, represented by a significant elevation of cell accumulation at $\mathrm{S} \%$ phase as well as on $\mathrm{G} 2 / \mathrm{M}$ phase, in contrast, a significant decrease in apoptosis \% was observed by many authors. ${ }^{[22,26,27]}$ The Ehrlich tumor is a rapidly growing carcinoma so that cells increase their nuclear materials continuously on the expense of their normal apoptotic rate. ${ }^{[28]}$ Accumulation of sub-G1 phase cells arrested in G1/G0 phase of the cell cycle as well, showed remarkable decrease in cells at $\mathrm{S} \%$ and $\mathrm{G} 2 / \mathrm{M}$ phase of the cell cycle. These findings establish the antiproliferative and apoptosis-inducing abilities of $\mathbf{T Q}$.

The activation of a defective $\mathrm{G} 1$ checkpoint apparent causes the accumulation of cells within the phase which might be due to the presence of wild-type p53 protein. The tumor suppressor protein p53 is the primary regulator of the $G 1$ checkpoint of cell cycle, where it co-ordinates the cellular ability of DNA repair with the binary decision between cell survival and death. [29] Hence, pre-treatment induced high fraction of cell death by apoptosis in EAC cells might be ascribed to the defective p53 checkpoint. ${ }^{[30-32]}$ The p53 tumor suppressor was initially identified as the guardian of the genome based on its ability to mediate G1 arrest following DNA damage. ${ }^{[33-34]}$ However, as indicated above, p53 is now known to act in many cellular processes, including cell-cycle checkpoints, DNA repair, senescence, angiogenesis, surveillance of genomic integrity and apoptosis. ${ }^{[35-36]}$

Anti-tumor properties of Nigella sativa were studied. [37-38] The active principle of Nigella sativa seeds was identified as a mixture of long-chain fatty acids. [37] These medicinal effects and others are due to thymoquinone (The major active constituents of Nigella sativa) which is a promising natural compound with important in vitro and in vivo anti-cancer activities against many different cancer cell lines, including cancers of the breast, colon, ovaries, lung and larynx, as well as myeloblastic leukemia, Ehrlich ascites carcinoma, Dalton's ascites lymphoma, and osteosarcoma. ${ }^{[39]}$ In the present study, subcutaneous inoculation with Ehrlich tumor cells was found to display increased eosinophilic, dense and pleomorphic nuclei, cytoplasmic vacuolization, hydropic degeneration (Oedema), leucocytic infiltration and necrosis. [40,41, 42] Moreover, leucocytic inflammatory infiltration was observed in liver of Ehrlich inoculated animals in the present study. These leucocytic infiltrations were considered as a prominent response of the body tissue facing any injurious impacts. ${ }^{[43]}$

The ultrastructural investigation of ESC inoculated animals showed a destruction or loss of microvilli in bile canaliculi and space of Disse with destruction of the endothelial cells. Decreased number of microvilli in both bile canaliculi and space of Disse has been noted in mice inoculated with hepatitis and after administration of carbon tetrachloride. ${ }^{[44-45]}$ In the present study, the anti-tumor activity of TQ may be due to the presence of fatty acids and may be also be due to other components. Ando et al. [46] suggested the possible mechanism involved in the anti-tumor activity of fatty acids. Firstly, the fatty acids acted as a detergent on the tumor cell membrane and subsequently altered or destroyed the cell membrane. ${ }^{[47]}$ Morgan et al. ${ }^{[48]}$ reported that the length of fatty acid carbon chain had some influences on the antitumor activity in vitro. A similar study using Nigella sativa seeds was carried out by Salomi et al. ${ }^{[37]}$ who concluded that in vivo EAC tumor development was completely inhibited by the active principle at the dose of $2 \mathrm{mg} / \mathrm{mouse}$ per day for 10 days. From the previous studies, attempt was undertaken to test the Nigella sativa seeds powder against the chemical carcinogenesis in rat liver. The present observations reinforce the view that TQ has potential scavenging power against EAC induced intracellular oxidative stress. Results of the present work are in agreement with those of Verrill ${ }^{[49]}$ who examined the potent anti-tumor activity of Zizyphus leaves extract against EAC cells , Saliva aegyptiaca and Trigonella foenum graecum which have a potential therapeutic effect on EAC bearing cells. ${ }^{[50]}$

Apoptosis is a pathway of cell death induced by a suicidal program in which cells destined to die by activate enzymes that degrade the cell nuclear DNA. [51] This is a normal 
phenomenon that serves to eliminate cells that are no longer needed during development. It is also a pathologic event when diseased cells become damaged beyond repair and are eliminated without eliciting a host reaction, thus limiting collateral tissue damage. ${ }^{[52]}$ Initiation of apoptosis occurs principally by signals from two distinct pathways: the intrinsic or mitochondrial pathway and the extrinsic or death receptorinitiated pathway. These pathways that are induced by distinct stimuli involve different sets of proteins. Both pathways converge to activate caspases, which are the actual mediators of cell death. ${ }^{[33]}$

However, besides significantly increasing the central area of necrosis, TQ treatment also promoted necrosis in the peripheral areas of the tumors, which are areas of undifferentiated and infiltrative proliferative neoplastic character. [54] TQ affects multiple targets, including suppression of anti-apoptotic genes expression and thus enhances apoptosis induction. ${ }^{[55]}$ Moreover, TQ inhibited cell proliferation of many types of cancer cell lines, including breast adenocarcinoma, ovarian adenocarcinoma, [56] human pancreatic adenocarcinoma, colorectal cancer, ${ }^{[39,57]}$ uterine sarcoma, [58] neoplastic keratinocytes [59] fibrosarcoma and lung carcinoma. ${ }^{[55]}$

Banerjee et al. ${ }^{[60]}$ have shown that more potent synthetic analogues of TQ can be prepared, which can potentially be developed for future human use. For instance, TQ has been shown to suppress the proliferation of various tumor cells, including colorectal carcinoma, breast adenocarcinoma, osteosarcoma, ovarian carcinoma, myeloblastic leukemia and pancreatic

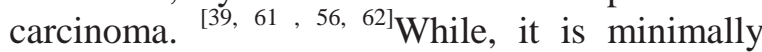
toxic to normal cells. ${ }^{[63]}$ Furthermore, we observed that endothelial cells were more sensitive to thymoquinone-induced cell apoptosis, cell proliferation and migration inhibition. Thus our results suggest that thymoquinone inhibits tumor angiogenesis and tumor growth, and can be used as a potential drug candidate for cancer therapy.

In conclusions: this study demonstrated that TQ has potential benefits in the prevention of the onset and progression of solid tumor model.

\section{REFERENCES}

1- Htasib H, Roessner A and Schneider-Stock R(2006): Thymoquinone: A promising anti-cancer drug from natural sources. Int. J. Biochem .Cell Biol., 38:1249-1253.

2- Dey K, Dey G, Pal I, Majumder A, Maiti Choudhury S, Kundu S and Mandal M(2012): Antineoplastic and Apoptotic Potential of Traditional Medicines Thymoquinone and Diosgenin in Squamous Cell Carcinoma. PLoS one,7: 46,641- 649. 3-Taha R, Gamal el-Din A and Abdel-Wahab M (2003): Thymoquinone is a potent superoxide anion scavenger. Drug Chem. Toxicol., 26:87-98.

4- Alam K, Badary O, al-Shabanah O, Al-Sawaf $\mathbf{H}$ and Al-Bekairi A(1999): Thymoquinone protects against carbon tetrachloride hepatotoxicity in mice via an antioxidant mechanism. Biochem Mo.1 .Biol Int., 47:153-159.

5- Abdel-Rahman M (1998): Hepatoprotective activity of thymoquinone in isolated rat hepatocytes. Toxicol Lett., 95:23-29.

6-El-Bolkiny $Y$ and Salem M(2010): Protective effects of Nigella sativa oil and thymoquinone against toxicity induced by the anticancer drug cyclophosphamide.Br. J. Biomed. Sci., 67:20-28.

7- Cherrah Y, Alaoui K, Mahassine N, Amarouch H, and Hassar M(2002): Effects of Nigella sativa fixed oil on blood homeostasis in rats. J. Ethnopharmacol., 79:23-26.

8- Alkhawajah A, Randhawa M, and Shaikh N (2008): Oral and intraperitoneal LD50 of thymoquinone an active principle of Nigella sativa, in mice and rats. J Ayub Med Coll Abbottabad., 20:2527.

9- Li F, Rajendran P, and Sethi G (2010): Thymoquinone inhibits proliferation, induces apoptosis and chemosensitizes human multiple myeloma cells through suppression of signal transducer and activator of transcription 3 activation pathway. Br. J. Pharmacol., 161: 541-554.

10- Woo CC, Loo S, Gee V, Yap C, and Sethi G (2011): Anticancer activity of thymoquinone in breast cancer cells: possible involvement of PPAR- $\gamma$ pathway. Biochem. Pharmacol., 82: 464-475.

11- Silva LA, Nascimento KA, Maciel MC, Pinheiro MT, Sousa PR, Ferreira SC, Azevedo AP, Guerra RN, and Nascimento FR (2006): Sunflower seed oil-enriched product can inhibit Ehrlich solid tumor growth in mice. Chemother., 52:91- 94.

12- Sakai M, De-Paula FV, Pinheiro ML, Ribeiro, A, Quinteiro-Filho WM, Martinez DB, Dagli ML, Palermo NJ, Papa DJ, and Rone MB (2010): Translocator protein $(18 \mathrm{kDa})$ mediates the progrowth effects of diazepam on Ehrlich tumor cells in vivo. Eur. J. Pharmacol., 626(2):131-138.

13- Wenger FA (2001): Influence of octreotide on liver metastasis and hepatic lipid peroxidation in 
BOP-induced pancreatic cancer in Syrian hamsters. Pancreas., 23(3): 266-72.

14- Gupta M (2004): Antitumor activity and antioxidant role of Bauhinia racemosa against Ehrlich ascites carcinoma in Swiss albino mice. Acta. Pharmacol. Sin., 25(8): 1070-6.

15- Badary OA, Al-Shabanah OA, Nagi MN, AlBekairi AM, and Elmazar MA (1998): Acute and Subchronic Toxicity of Thymoquinone in Mice. Drug Dev. Res., 44(2):56-61.

16- Nagi MN, Alam K, Badary OA, A1-Shabanah OA, A1-Sawaf HA, and A1-Bekairy AM (1999): Thymoquinone protects against carbon tetrachloride hepatotoxcicity in mice via an antioxidant mechanism. Biochem. Mol. Int., 47(1): 153-159.

17- Badr El-Din NK, Ghoneum M, Noaman E, and Tolentino L(2007): Saccharomyces cerevisiae, the Baker's Yeast, suppresses the growth of Ehrlich carcinoma-bearing mice . Canc. Immunol. Immunother., 57(4):581-592.

18- Dean PN, and Jett JH(1974): Mathematical analysis of DNA distributions derived from flow micro flurometry. J. Cell Biol., 60(1): 523-527.

19- Nicoletti I, Mannucci R, Migliorati G, Riccardi C, and Grignani F(2001): Common method for measuring apoptotic cell death by flow cytometry. Purdue Cytom CD-ROM Ser., 3(1):1-9.

20- Brotherick I, Shenton BK, Cowan WK, Angus B, Horne CW, Higgs MJ, and Lennard T J (1995): p53 expression measured by flow cytometry. A comparison of three monoclonal antibodies and the relationship with grade and DNA ploidy in breast cancer. Cancer Immunol. Immunother., 41:146-150.

21- Fukuzawa $Y$, Watanabe $Y$, Inaguma $D$, and Hotta N(1996): Evaluation of glomerular lesion and abnormal urinary findings in OLETF rats resulting from a long-term diabetic state. J Lab. Clin. Med., 128:568-578.

22- Badr El-Din NK, Ghoneum M, and Noaman E (2008): In Vivo Tumor Inhibitory Effects of Nutritional Rice Bran Supplement MGN-3/Biobran on Ehrlich Carcinoma- Bearing Mice. Nutr. Canc., 60(2), 235-244.

23- Vilelaa AM, Portilhoa FP, de Araujoa VG, Estevanatoa LC, Mezzomo BP, de Fátima MM, Santosb AA, and Lacavaa ZG(2011): The protective effects of nutritional antioxidant therapy on Ehrlich solid tumorbearing mice depend on the type of antioxidant therapy chosen: histology, genotoxicity and hematology evaluations. J. Nutr. Biochem., 22 (1): 1091-1098.

24- Metwally FM, El-Mezayen HA, Abdel Moneim AE, and Sharaf NE (2014): Anti-Tumor Effect of Azadirachta indica (Neem) on Murine Solid Ehrlich Carcinoma . J. Canc. Res., 7 (1): 38 -45
25- Asfour W, Almadi S, and Haffar L (2013): Thymoquinone Suppresses Cellular Proliferation, Inhibits VEGF Production and Obstructs Tumor Progression and Invasion in the Rat Model of DMHInduced Colon Carcinogenesis . Pharma.col . Pharm .,4(1): 7-17.

26- Bhattacharyya A, Choudhuri T, Pal S, Chattopadhyay S, Datta GK, Sa G, and Das T (2003): Apoptogenic effects of black tea on Ehrlich's ascites carcinoma cell. Carcinog., 24 (1) :75-80 .

27- Noaman E, Fahmy N, Yousri R, El Shawi O, and Ghazy $M$ (2011): Evaluation of the Antitumor and Radiosynthetizing Activity of a Novel Quinoline Sulfonamide Derivative (PIQSA) as a Histone Deacetylase Inhibitor. J. Canc. Ther., 2(1): 567-578.

28- Biswas G, Chatterjee S, and Acharya K(2012): Chemopreventive Activity of The Ethanolic Extract of Astraeus Hygrometricus (PERS.)MORG.on Ehrlich's Ascites Carcinoma cells. Dig. J. Nanomater Bios., 7(1): 185-191.

29- Kastan MB(2008): DNA damage responses: mechanisms and roles in human disease. Mol. Canc. Res., 6:517-524.

30- Arafa EA, Zhu Q, Shah ZI, Gulzar G, Barakat BM, Racoma I, El-Mahdy MA, and Wani AA(2011): Thymoquinone up-regulates PTEN expression and induces apoptosis in doxorubicinresistant human breast cancer cells. Mutat. Res., 706(1-2): 1-20.

31- Salim LZ, Mohan S, Othman R, Abdelwahab SI, Kamalidehghan B, Sheikh BY, and Ibrahim MY(2013): Thymoquinone Induces MitochondriaMediated Apoptosis in Acute Lymphoblastic Leukaemia in Vitro. Molecules ., 18: 11219-11240.

32- Chu SC, Hsieh YS, Yu CC, Yi Y, Lai YY, and Chen PN (2014): Thymoquinone Induces Cell Death in Human Squamous Carcinoma Cells via Caspase Activation-Dependent Apoptosis and LC3-II Activation-Dependent Autophagy. PloS. ONE., 9(7): $1-12$.

33- Kuerbitz SJ, Plunkett BS, Walsh WV, and Kastan MB(1992): Wild - type p53 is a cell cycle check point determinant following irradiation. Proc. Natl. Acad. Sci. USA, 89(16): 7491-7495.

34- Lane DP (1992) : p53, guardian of the genome. Nat., 358: 15-16.

35- Ko LJ, and Prives C (1996): p53: puzzle and paradigm. Gene. Dev., 10(9): 1054 - 1072.

36- Evan GI, and Vousden KH (2001): Proliferation, cell cycle and apoptosis in cancer. Nat., 411, 342348.

37- Salomi NG, Nair SC, Jayawardhanan KK, Varghese CD,and Panikkar KR (1992): Antitumour principles from Nigella sativa seeds. Canc. Lett., 63(1):41-46. 
38- Hasan TN, Shafi G, Syed NA, Alfawaz MA, Alsaif MA, Munshi A, Lei KY, and Alshatwi AA (2013): Methanolic extract of Nigella sativa seed inhibits $\mathrm{SiHa}$ human cervical cancer cell proliferation through apoptosis. Nat. Prod. Commun., 8(2):213-6.

39- Muhtasib HG, Diab AM, Boltz C, Al-Hmaira J, Hartig R, Roessner A, and Stock SR (2004a): Thymoquinone extracted from black seed triggers apoptotic cell death in human colorectal cancer via a p53-dependent mechanism. Int. J. Oncol., 25(4): 857866.

40- Farag AM, and Abdel Dayem SM(2001): Biochemical, histological and ultrastructural studies on the protective effect of vitamin A against carcinogenesic effect of 7, 12-DMBA on the liver of albino rat. J. Zool., 37:335-368.

41- Islam F, Ali SM,and Khanam JA (2013): Hepatoprotective effect of acetone semicarbazone on Ehrlich ascites carcinoma induced carcinogenesis in experimental mice. Asian Pacific J. tropical Biomed., 3(2):105-110.

42- El-Batal AI, Abou Zaid OA, Noaman E, and Ismail ES (2012): In vivo and in vitro antitumor activity of modified citrus pectin in combination with selenium nanoparticles against Ehrlich carcinoma cells. Int. J. Pharm Sci. Health care., 6(2):23-47.

43- Sakr SA (1999): Pyrethroid inhalation induced hepatotoxicity in albino rats. Oxford Res. Forum J., 1:27-32.

44- Reynolds ES (1963): Liver Parenchymal Cell Injury. I. Initial Alterations of the Cell Following Poisoning with Carbon Tetrachloride. J. cell biol., 19:139-157.

45- Sherlock S, and Dooley J(1997): Diseases of the Liver and Biliary System. $9^{\text {th }}$ ed. Germany: WileyBlackwell.

46- Ando K, Suzuki S, and Arita M (1970): Synthesis of mycophenolic acid beta-D-glucuronide and its antitumor activity. J. Antibiot (Tokyo), 23(8):408-413.

47-Das AK (1989): Antitumor property of the active principle of jawaharene. Canc. Lett., 48(2):147-151.

48- Morgan JF, Tolnai S, and Townsend GF (1960): Studies on the in vitro antitumor activity of fatty acids. II. Saturated dicarboxylic acids. Can. J. Biochem Physiol., 38:597-603.

49- Verrill M (2009): Chemotherapy for early-stage breast cancer: a brief history. Br. J. Canc., 101(1):S2S5.

50- Tohamy AA, Ibrahim SR, and Abdel Moneim AE (2013): Trigonella foenum graecum and Saliva aegyptiaca modulates hepatic redox status in Ehrlichascites-carcinoma-bearing mice. J. Appl. Pharm. Sci ., 3 (11): 45-50.
51- Kumar V, Abbas A, Fausto N, and Aster J(2009): Cellular responses to stress and toxic insults: Adaptation, injury and death. In Robbins and Cortan Pathologic Basis of Disease $\left(8^{\text {th }}\right.$ ed $)$.

52- Fadeel B, and Orrenius S (2005): Apoptosis: a basic biological phenomenon with wide-ranging implications in human disease. J. Int. Med., 258(6):479-517.

53- Danial NN,and Korsmeyer SJ (2004): Cell death: critical control points. Cell., 116(2):205-219.

54- Stewart HL, Snell KC, Dunham LJ, and Schylen SM (1959). Transplantable and Transmissible Tumors of Animals: Atlas of Tumor Pathology. Washington: Armed Fource Institute of Pathology.

55- Kaseb AO, Chinnakannu K, Chen D, Sivanandam A, Tejwani S, Menon M, Dou QP, and Veer Reddy GP (2007): Androgen Receptor- and E2F-1Targeted Thymoquinone Therapy for Hormone-Refractory Prostate Cancer. Canc. Res., 67 (16): 7782-7788.

56- Shoieb AM, Elgayyar M, Dudrick PS, Bell JL, and Tithof PK (2003): In vitro inhibition of growth and induction of apoptosis in cancer cell lines by thymoquinone. Int. J. Oncol., 22(1):107-113.

57- Muhtasib HG, Assaf DM, and Haddadin MJ (2005): Quinoxaline 1, 4-dioxides induce G2/M cell cycle arrest and apoptosis in human colon cancer cells. Canc. Chemother pharmacol., 55(4):369-378.

58- Worthen DR, Chien L, Tsuboi CP, Mu XY, Bartik MM, and Crooks PA. (1998a): LCanavanine modulates cellular growth, chemosensitivity and P-glycoprotein substrate accumulation in cultured human tumor cell lines. Canc. Lett., 132(1-2):229-239.

59- Muhtasib HG, Abou Kheir WG, Kheir LA, Darwiche N, and Crooks PA (2004b): Molecular pathway for thymoquinone-induced cell-cycle arrest and apoptosis in neoplastic keratinocytes. Anti. Canc. drug., 15(4):389-399.

60- Banerjee S, Azmi AS, Padhye S, Singh MW, Baruah JB, Philip PA, Sarkar FH, and Mohammad RM (2010): Structure-activity studies on therapeutic potential of Thymoquinone analogs in pancreatic cancer. Pharmaceut. Res., 27(6):1146-1158. 61- Muhtasib HG, Roessner A, and SchneiderStock R(2006): Thymoquinone: a promising anticancer drug from natural sources. Int. J. Biochem. Cell Biol., 38(8): 1249-1253.

62- El-Mahdy MA, Zhu Q, Wang Q, Wani G, and Wani AA (2005): Thymoquinone induces apoptosisthrough activation of caspase 8 and mitochondrial events in p53-null myeloblastic leukemia HL- 60 cells. Int. J. Canc., 117: 409-417.

63- Worthen DR, Ghosheh OA, and Crooks PA (1998b): The in vitro anti-tumor activity of some crude and purified components of black seed, Nigella sativa L. Anti. Canc. Res., 18(3A): 1527-1532. 
Sayed K, Areida et al

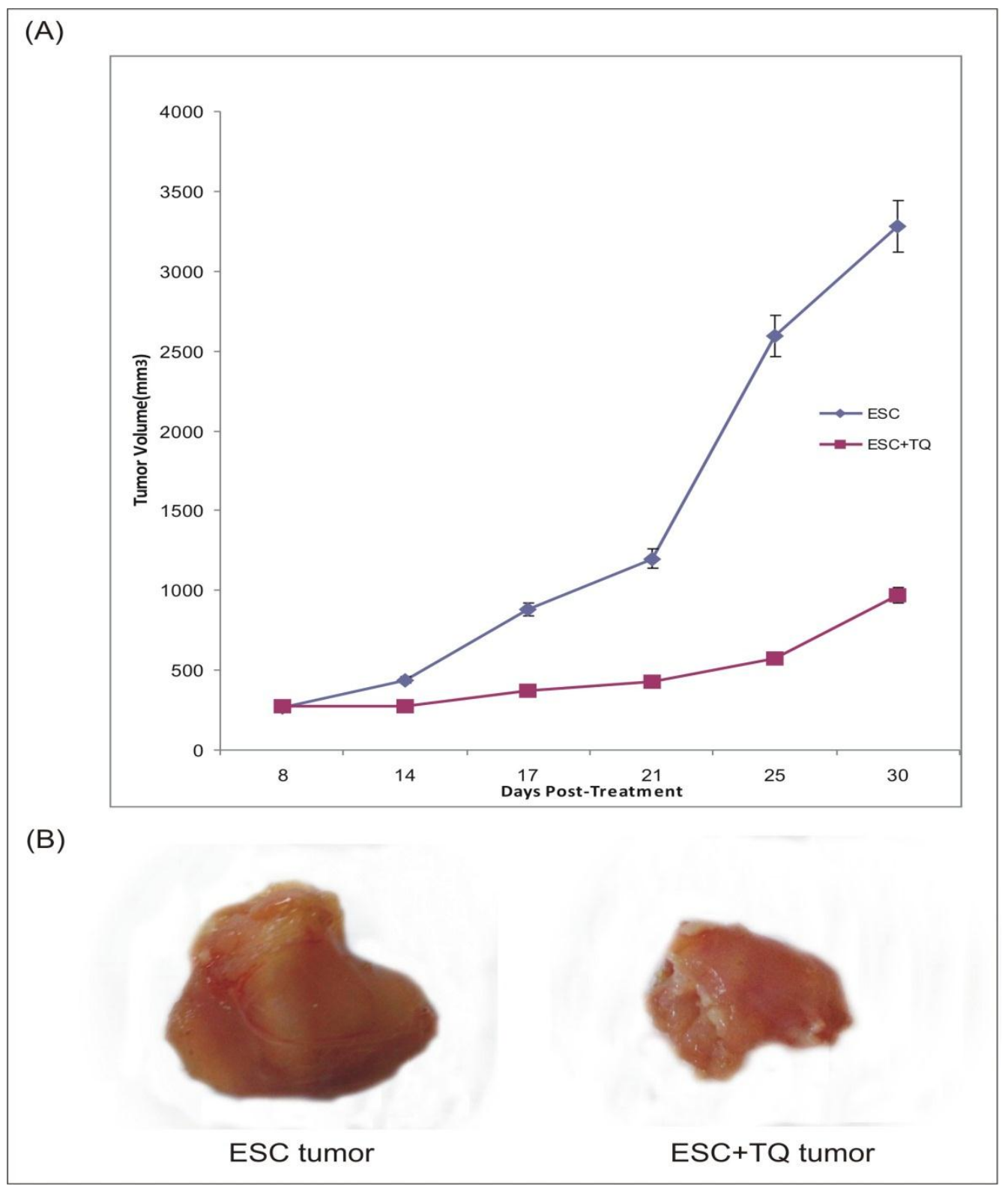

Fig.1: Effect of TQ administration on tumor volume $\left(\mathrm{mm}^{3}\right)$ and morphology in mice- bearing Ehrlich solid carcinoma.(A) .Histogram of tumor volume in ESC and ESC+TQ treated group. BMorphological appearance of solid Ehrlich tumor in ESC and ESC+TQ treated group. 
Protective and Curative Effect of Thymoquinone...

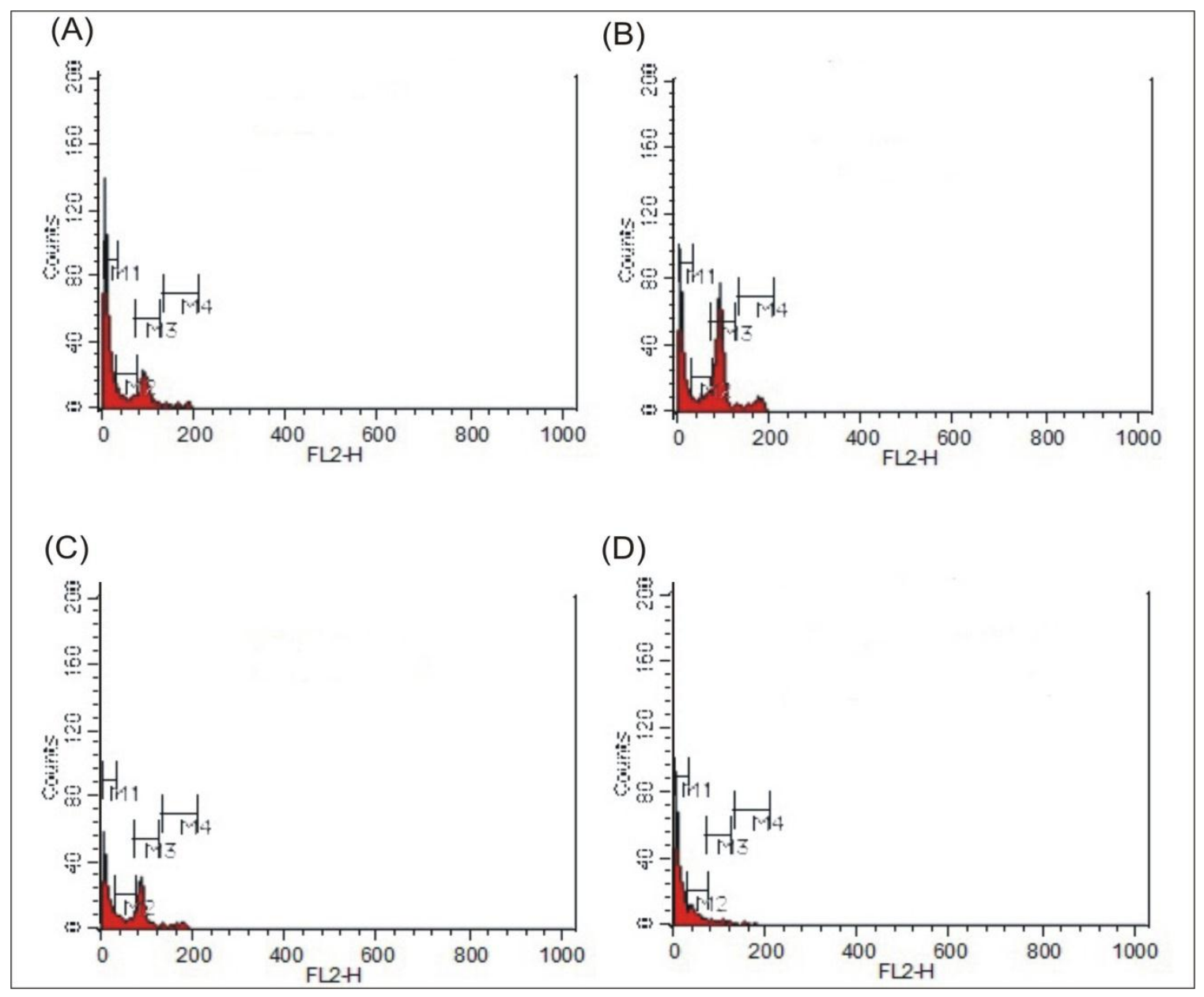

Fig. 2: Flow cytometric analysis of Ehrlich solid tumor cell cycle phase distribution. A- Control TQ group, B- ESC group, C- ESC+TQ group and D- TQ+ESC group. 
Sayed K, Areida et al

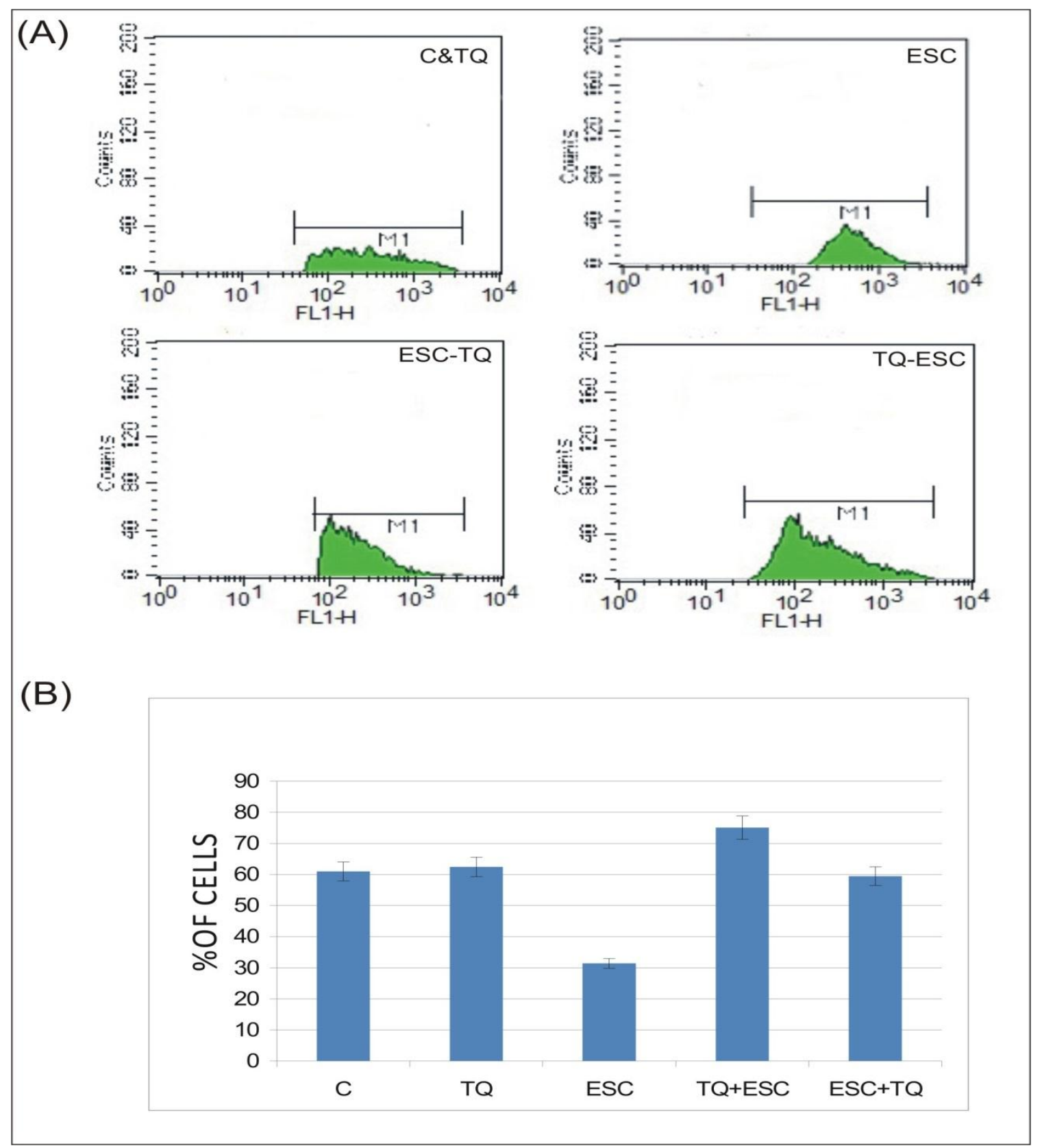

Fig. 3: Expression of p53 protein in the different treated groups of mice. A- Flow cytometric analysis of p53. B- Histograms of flow cytometric analysis of p53 protein expression in the different treated groups. 


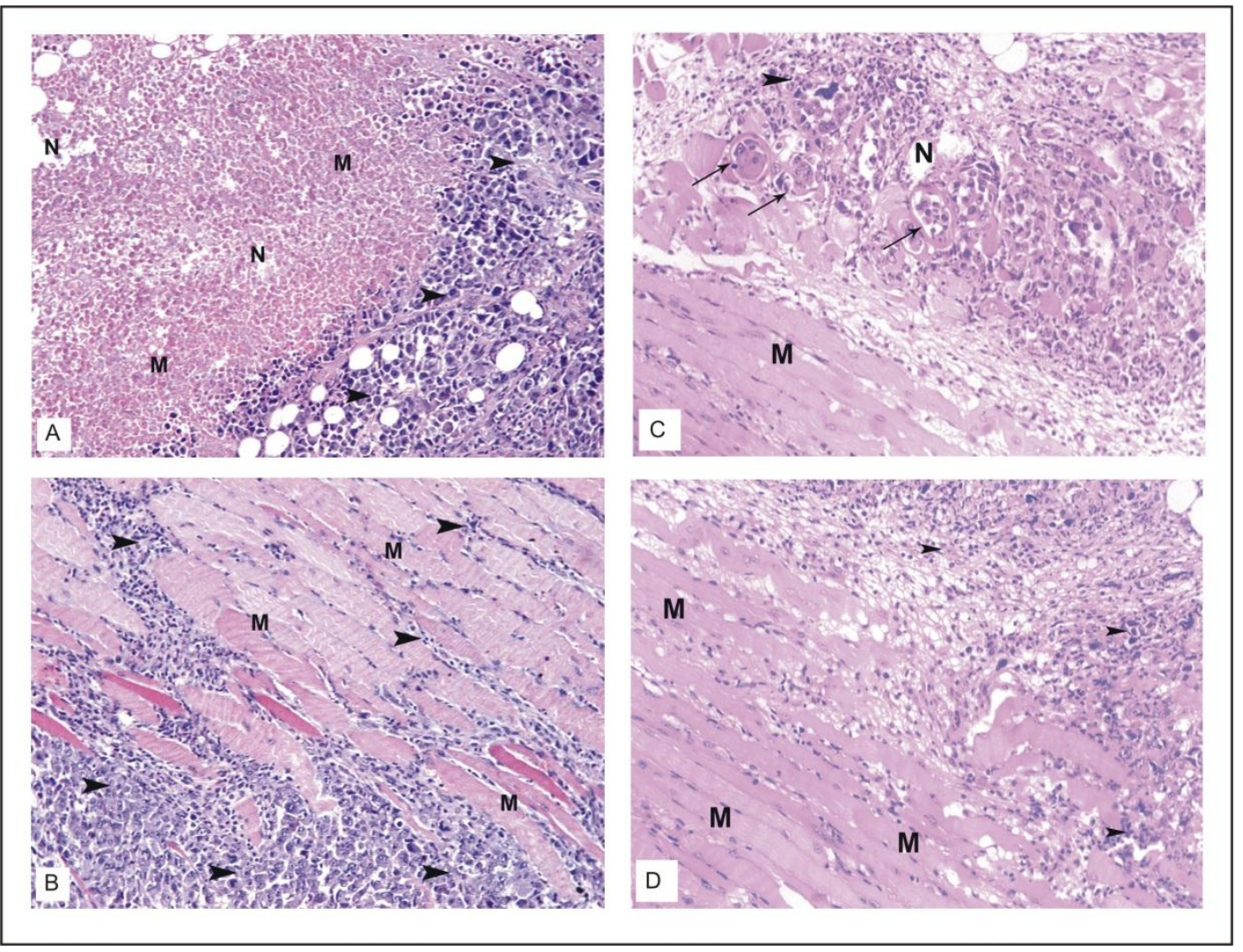

Fig.4: Histopathology of solid Ehrlich carcinoma tumor (SEC) of mice. (A and B ) longitudinal sections of Ehrlich tumor bearing mice; thigh muscle displaying muscle fibres (M) invaded by deeply stained tumor cells (arrow heads) and large area of necrosis (N). ( C and D) Sections of Ehrlich tumor bearing mice with TQ showing a partial prevention of the effects of EAC cells by thymoquinone, and muscle fibres (M) invaded by deeply stained tumor cells (arrow heads). 


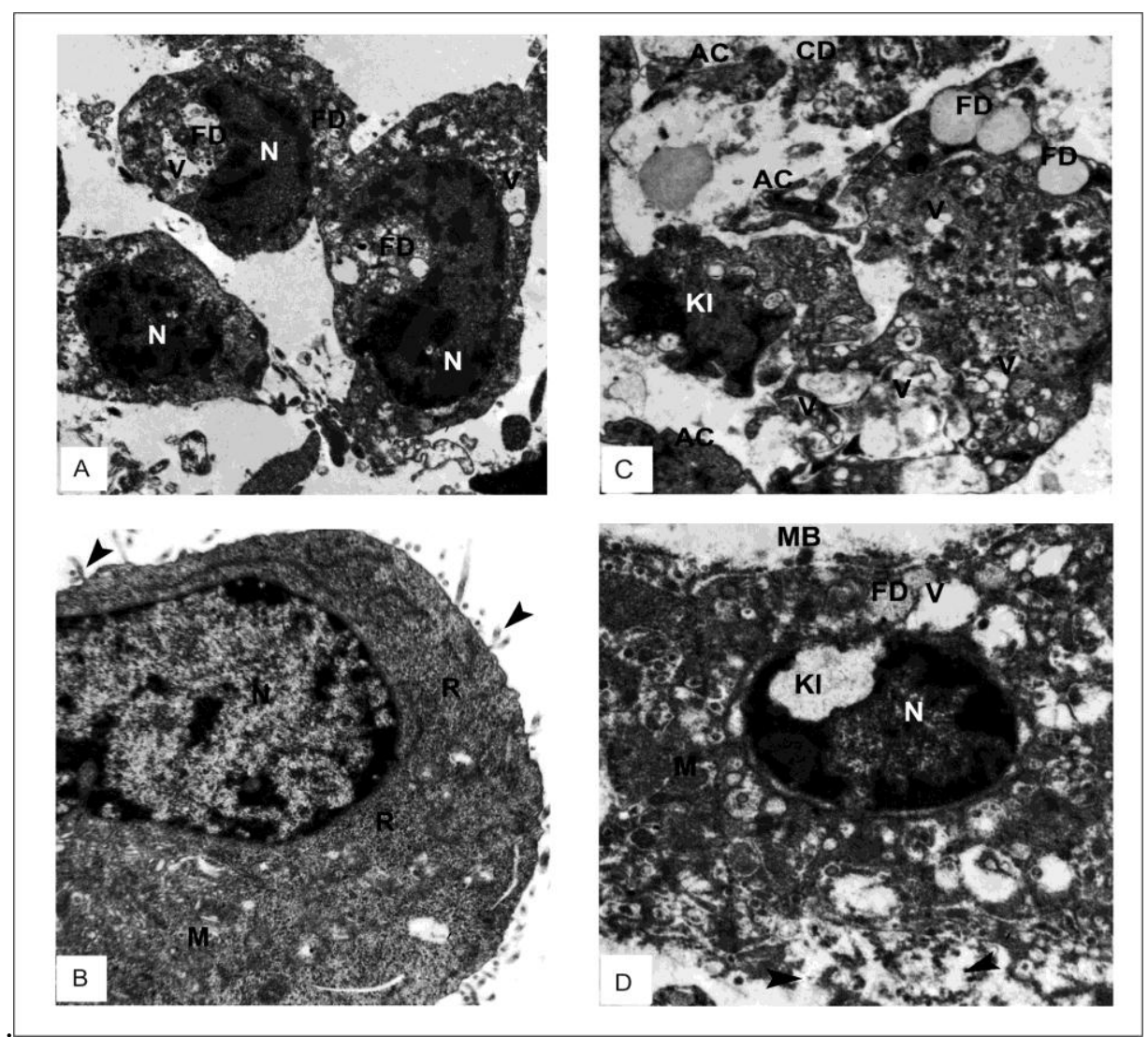

Fig. 5: The ultrastructural estimation of solid Ehrlich carcinoma tumor (SEC) of mice. (A and B) Electron micrographs of Ehrlich solid tumor showing large nucleus (N) with condensed chromatin, many vacuoles (V), fat droplets (FD), microvilli (arrow), (R) ribosomes and mitochondria (M). (C and D) Electron micrographs of Ehrlich solid tumor treated with TQ showing many vacuoles (V), fat droplets (FD), karyolysis $(\mathrm{Kl})$, cell debris (CD), fragmented cells (*), karyolysis (Kl), many vacuoles (V), fat droplets (FD), mitochondria (M), membrane blebs (MB), (arrow heads) and necrosis. 
Table 1- Protective effect of TQ on $\%$ of body weight change and tumor sizes of the different treatments groups.

\begin{tabular}{|c|c|c|c|c|c|}
\hline \multirow[t]{2}{*}{ Parameters } & \multicolumn{5}{|l|}{ Group } \\
\hline & C & TQ & ESC & TQ+ESC & ESC+TQ \\
\hline $\begin{array}{l}\text { Initial body weight (g) (at } \\
\text { day 0) }\end{array}$ & $20.1 \pm 0.1$ & $20.63 \pm 0.12$ & $20.78 \pm 0.24$ & $20.6 \pm 0.17$ & $20.6 \pm 0.01$ \\
\hline $\begin{array}{l}\text { Final body weight (g) (at } \\
\text { day } 30 \text { ) }\end{array}$ & $26.73 \pm 0.14$ & $27.2 \pm 0.3$ & $26.5 \pm 0.7$ & $27 \pm 0.05$ & $26.6 \pm 0.3$ \\
\hline $\begin{array}{l}\text { Tumor weight (g)(at day } \\
30 \text { ) }\end{array}$ & -- & -- & $6.31^{\mathrm{a}} \pm 0.04$ & -- & $2.85^{\mathrm{a}, \mathrm{b}} \pm 0.24$ \\
\hline Net final body weight (g) & $26.73^{\mathrm{b}} \pm 0.14$ & $27.2^{\mathrm{b}} \pm 0.3$ & $20.1^{\mathrm{a}} \pm 0.7$ & $27^{\mathrm{b}} \pm 0.05$ & $23.73^{\mathrm{a}, \mathrm{b}} \pm 0.31$ \\
\hline Body weight gain $(\mathrm{g})$ & $+6.73^{\mathrm{b}}$ & $+6.56^{\mathrm{b}}$ & $-0.68^{\mathrm{a}}$ & $+6.4^{\mathrm{b}}$ & $+3.13^{\mathrm{a}, \mathrm{b}}$ \\
\hline$\%$ of body wt. change & $(+33.48 \%)$ & $(+31.79 \%)$ & $(-3.27 \%)$ & $(+31.06 \%)$ & $(+15.19 \%)$ \\
\hline
\end{tabular}

Data are expressed as mean $\pm \mathrm{SE}$, (a) significant coompared to the control $\mathrm{P}<0.05$

, (b) significant compared to ESC, $\mathrm{P}<0.05$.

Table 2- Flow cytometric analysis of cell cycle distribution in the different treated groups.

\begin{tabular}{|c|c|c|c|c|c|}
\hline ESC+TQ & TQ+ESC & ESC & TQ & $\mathbf{C}$ & Groups \\
\hline $\begin{array}{c}45.08 \\
\pm \\
0.04^{\mathrm{a}, \mathrm{b}}\end{array}$ & $\begin{array}{c}73.85 \\
\pm^{ \pm} \\
0.7^{\mathrm{a}, \mathrm{b}}\end{array}$ & $\begin{array}{c}31.45 \\
\pm \\
0.22^{\mathrm{a}}\end{array}$ & $\begin{array}{c}65.08 \\
\pm \\
0.64^{b}\end{array}$ & $\begin{array}{c}64.44 \\
\pm \\
0.64^{b}\end{array}$ & $\begin{array}{c}\text { Apoptosis } \\
\text { (M1) } \\
\%\end{array}$ \\
\hline $\begin{array}{c}15.85 \\
\pm \\
0.01^{\mathrm{b}}\end{array}$ & $\begin{array}{c}23.73 \\
\pm \\
0.34^{\mathrm{a}, \mathrm{b}}\end{array}$ & $\begin{array}{c}12.26 \\
\pm \\
0.14^{\mathrm{a}}\end{array}$ & $\begin{array}{c}15.7 \\
\pm \\
0.51^{\mathrm{b}}\end{array}$ & $\begin{array}{c}15.18 \\
\pm \\
0.52^{\mathrm{b}}\end{array}$ & $\begin{array}{c}\text { G0/G1phase } \\
\text { (M2) } \\
\%\end{array}$ \\
\hline $\begin{array}{c}37.73 \\
\pm \\
0.04^{\mathrm{a}, \mathrm{b}}\end{array}$ & $\begin{array}{c}7.82 \\
\pm \\
0.57^{\mathrm{a}, \mathrm{b}}\end{array}$ & $\begin{array}{c}52.29 \\
\pm \\
0.09^{\mathrm{a}}\end{array}$ & $\begin{array}{c}22.6 \\
\pm \\
1.21^{\mathrm{b}}\end{array}$ & $\begin{array}{c}23.78 \\
\pm \\
1.17^{\mathrm{b}}\end{array}$ & $\begin{array}{c}\text { S phase } \\
\text { (M3) } \\
\%\end{array}$ \\
\hline $\begin{array}{c}5.72 \\
\pm \\
0.01^{\mathrm{a}, \mathrm{b}}\end{array}$ & $\begin{array}{c}1.87 \\
\pm \\
0.19^{\mathrm{a}, \mathrm{b}}\end{array}$ & $\begin{array}{c}7.84 \\
\pm \\
0.02^{\mathrm{a}}\end{array}$ & $\begin{array}{c}2.41 \\
\pm \\
0.12^{\mathrm{b}}\end{array}$ & $\begin{array}{c}2.53 \\
\pm \\
0.11^{\mathrm{b}}\end{array}$ & $\begin{array}{c}\text { G2/M phase } \\
\text { (M4) } \\
\%\end{array}$ \\
\hline
\end{tabular}

$\mathrm{a}=$ significant as compared to the control group $(\mathrm{P}<0.05) . \mathrm{b}=$ significant as compared to ESC treated group $(\mathrm{P}<0.05)$ 